\title{
VERG. AEN. 2. 351-352: EVOCATIO UNDER TROY?
}

\section{Roman A. Isaenko}

St. Petersburg State University,

7-9 Universitetskaya nab., St. Petersburg, 199034, Russian Federation; isaenkora@mail.ru

The article concerns two verses from Virgil's Aeneid which are uttered by Aeneas as he witnessed the the fall of Troy and noted that the city had been abandoned by the gods. Macrobius and Servius consider these verses to indicate that before the assault on Troy the Achaeans performed the ritual of evocatio, which a commander had to accomplish addressing the tutelary deities of a besieged city and asking them to take the attackers' side in exchange for worship on their part. The article's aim is to criticize this interpretation and to offer a possible reason for its emergence.

Keywords: evocatio, Virgil, Aeneid, Servius, Macrobius.

During the sacking of Troy as depicted in Vergil's Aeneis, Aeneas seeks to inspire his compatriots to take part in one last, hopeless battle and accept a dignified death together with the city that has proved to be beyond salvation. His brief, but passionate speech includes the following words (2.351-352):

excessere omnes adytis arisque relictis

di, quibus imperium hoc steterat.

'All the gods on whom this empire was stayed have gone forth, leaving shrine and altar.' (Transl. Fairclough, Goold 1918).

At least two ancient authors considered these verses to be a reference to a particular Roman wartime ritual known as evocatio. The verb excessere receives the following comment from Servius:

excessere quia ante expugnationem evocabantur ab hostibus numina propter vitanda sacrilegia.

'They have gone forth, because deities used to be called away from enemies before a siege in order to avoid sacrileges.'

This opinion is shared by Macrobius, who quotes the verses at the very beginning of a passage devoted to evocatio, but is less certain about the ritual's purpose and offers two explanations for it (Sat. 3. 9):

constat enim omnes urbes in alicuius dei esse tutela, moremque Romanorum arcanum et multis ignotum fuisse ut, cum obsiderent urbem hostium eamque iam capi posse confiderent, certo carmine evocarent tutelares deos, quod aut aliter urbem capi posse non crederent, aut etiam, si posset, nefas aestimarent deos habere captivos.

'For it is commonly understood that all cities are protected by some god, and that it was secret custom of the Romans (one unknown to many) that when they were laying siege to an enemy city and were confident it could be taken, they used a specific spell to call out the gods that pro-

(C) St. Petersburg State University, 2017 
tected it, because they either believed the city could otherwise not be taken or-even if it could be taken - thought it against divine law to hold gods captive.' (Transl. Kaster 2011).

If Servius and Macrobius are correct in their interpretation of Vergil, and it is the intention of the poet to imply that the Greeks had performed the ritual of evocatio before they began their assault on Troy, the Aeneis proves to be the earliest surviving literary work to mention this ritual, coming ahead of Pliny the Elder's Naturalis Historia by almost a century.

Some authors of the more contemporary commentaries on the Aeneis appear to share the opinion of Servius and Macrobius. T.E. Page refers to the Saturnalia without expressing any doubts in its relevancy: "There was a regular formula (carmen quo dii evocantur) for summoning the gods of a besieged city to leave it; Macr. 3. 9." (Page 1967, 234). A. Sidgwick reproduces this interpretation: "The Romans believed that the gods left a falling city, and when they had a siege, used to call out the gods, and transfer their rites to Rome." (Sidgwick 1884, 58). R. G. Austin develops Macrobius' idea further by hypothesizing that Vergil's choice of words may be influenced by a formula similar to the one recorded in the Saturnalia: "Possibly Virgil's adytis arisque relictis may preserve a trace of some such formula." (Austin 1973, 153-154). Others are more careful in their assessments. Among them is J. Connington who claims that the practice of evocatio is merely related to the belief reflected in the Aeneis: "The custom of 'evocatio', which arose from this belief, seems to have been peculiar to the Romans." (Connington 1863, 142).

It is true that it would not be out of character for Vergil to ascribe distinctly Roman cultural traits to the Greeks. For example, in his depiction of the assault on the house of Priam, the Greek forces make use of testudo, a Roman combat formation, to shield themselves from arrows (2. 440-441):

sic Martem indomitum Danaosque ad tecta ruentis

cernimus obsessumque acta testudine limen.

'So do we see the god of war unbridled, Danaans rushing to the roof and the threshold beset with an assaulting mantlet of shields' (Transl. Fairclough, Goold 1918).

Earlier, Sinon claims that Calchas advised the Greeks to return to Argos and seek more favorable omens there because they had offended Athena (2. 176-178):

extemplo temptanda fuga canit aequora Calchas,

nec posse Argolicis exscindi Pergama telis

omina ni repetant Argis numenque reducant.

'Straightway Calchas prophesies that the seas must be essayed in flight, and that Pergamus cannot be uptorn by Argive weapons, unless they seek new omens at Argos.' (Transl. Fairclough, Goold 1918).

Servius recognizes this practice as Roman:

et respexit Romanum morem: nam si egressi male pugnassent, revertebantur ad captanda rursus auguria.

'He acknowledged a Roman custom, for the Romans used to come back in order to obtain auguries once again, if they had marched out, but performed poorly in battle.' 
However, claiming that the Greeks performed evocatio before their final assault on Troy would interfere with accomplishing the ideological goals that Vergil pursues. It is an aim of the poem to portray Rome as the successor of Troy, with religious continuity serving as the principal link between the two cities. It is the task of finding a new home for the Trojan Penates that the spirit of Hector charges Aeneas with before he embarks on his journey (2.293-295):

sacra suosque tibi commendat Troia Penates:

hos cape fatorum comites, his moenia quaere,

magna pererrato statues quae denique ponto.

'Troy entrusts to you her holy things and household gods; take them to share your fortunes: seek for them the mighty city, which, when you have wandered over the deep, you shall at last establish!' (Transl. Fairclough, Goold 1918).

Aeneas' mission receives recurring mentions throughout the entire poem. The first instance can be found as early as the opening lines of book 1 (1. 1-7):

Arma virumque cano, Troiae qui primus ab oris

Italiam, fato profugus, Laviniaque venit

litora, multum ille et terris iactatus et alto

vi superum saevae memorem Iunonis ob iram;

multa quoque et bello passus, dum conderet urbem,

inferretque deos Latio, genus unde Latinum,

Albanique patres, atque altae moenia Romae.

'Arms and the man I sing, who first from the coasts of Troy, exiled by fate, came to Italy and Lavine shores; much buffeted on sea and land by violence from above, through cruel Juno's unforgiving wrath, and much enduring in war also, till he should build a city and bring his gods to Latium; whence came the Latin race, the lords of Alba, and the lofty walls of Rome.' (Transl. Fairclough, Goold 1918).

At the beginning of book 3 , the images of Trojan deities make up the few possessions mentioned by Aeneas describing his departure. Notably, the Penates and di magni are listed separately, potentially indicating that the familial gods of the royal house are not the only deities to be transferred to Rome by Aeneas (3.10-12):

litora cum patriae lacrimans portusque relinquo

et campos, ubi Troia fuit. feror exsul in altum

cum sociis natoque, Penatibus et magnis dis.

'And then with tears I quit my native shores and harbours, and the plains, where once was Troy. An exile, I fare forth upon the deep, with my comrades and son, my household gods and the great deities.' (Transl. Fairclough, Goold 1918).

The line 3. 12 is echoed in the depiction of the Battle of Actium seen on Aeneas' shield, establishing Augustus as a worthy heir of his ancestors (8. 678-681):

hinc Augustus agens Italos in proelia Caesar cum patribus populoque, Penatibus et magnis dis, stans celsa in puppi, geminas cui tempora flammas laeta uomunt patriumque aperitur uertice sidus. 
'On the one side Augustus Caesar stands on the lofty stern, leading Italians to strife, with Senate and People, the Penates of the state and all the mighty gods; his auspicious brows shoot forth a double flame, and on his head dawns his father's star.' (Transl. Fairclough, Goold 1918).

If the Greeks were to perform evocatio under the walls of Troy, the exceptional status of Rome would be diminished because the ritual involved replicating the cults of the summoned deities in the homeland of the invaders. Greece would come into possession of Troy's religious legacy that is supposed to belong to Rome alone.

Therefore, it is likely that Vergil intends to express a different idea with his verses. Other depictions of gods leaving a conquered city that fail to mention the ritual of evocatio can be found in various Greek and Roman texts, some of which specifically concern Troy. In the opening scene of Euripides' Troades, set shortly after the fall of Troy, but before the departure of the Greeks, Poseidon voices his intention to leave because religion cannot exist in a deserted city (23-27):

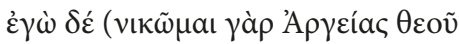

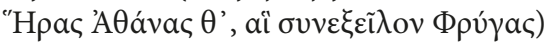

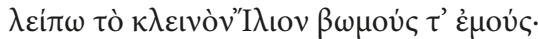

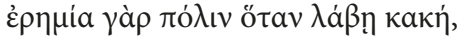

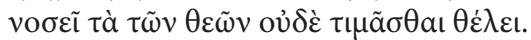

'Vanquished by Hera, Argive goddess, and by Athena, who helped to ruin Phrygia, I am leaving Ilium, that famous town, and the altars that I love; for when drear desolation seizes on a town, the worship of the gods decays and tends to lose respect.' (Transl. Coleridge 1910).

Similar motives appear to be attributed to the gods of Troy in the scholia on Aeschylus that reference a lost play (schol. ad Septem 304):

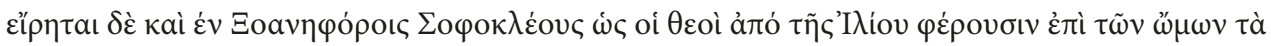

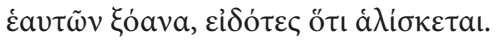

'In Sophocles' Image-Bearers, it is also said that the gods carried their own images on their shoulders out of Ilion, having realized that the city was taken.'

Tacitus names the departure of the gods among the omens that preceded the fall of Jerusalem in $70 \mathrm{CE}$ (Hist. 5. 13):

Visae per caelum concurrere acies, rutilantia arma et subito nubium igne conlucere templum. Apertae repente delubri fores et audita maior humana vox excedere deos; simul ingens motus excedentium.

'There had been seen hosts joining battle in the skies, the fiery gleam of arms, the temple illuminated by a sudden radiance from the clouds. The doors of the inner shrine were suddenly thrown open, and a voice of more than mortal tone was heard to cry that the Gods were departing. At the same instant there was a mighty stir as of departure.' (Transl. A. J. Church, W. J. Brodribb 1894).

A similar account can be found in Josephus (Bel. Iud. 6. 299):

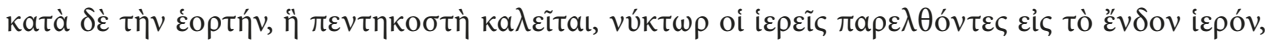

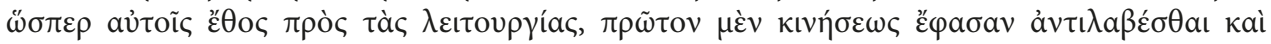

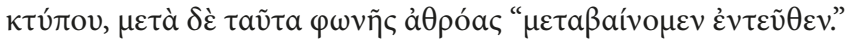


'Moreover, at that feast which we call Pentecost, as the priests were going by night into the inner [court of the temple,] as their custom was, to perform their sacred ministrations, they said that, in the first place, they felt a quaking, and heard a great noise, and after that they heard a sound as of a great multitude, saying, «Let us remove hence.»" (Transl. Whiston 1878).

The belief in the gods' willingness to abandon doomed cities is also reflected in Diodorus' account of the siege of Tyre by Alexander the Great (Bib. Hist. 17. 41. 7-8):

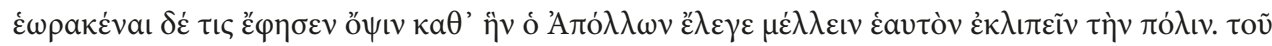

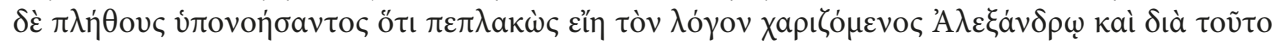

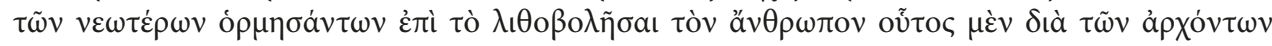

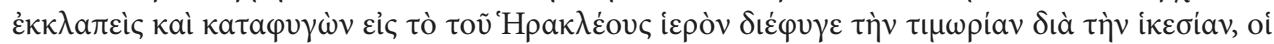

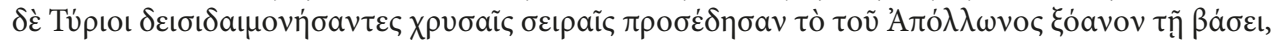

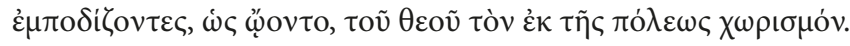

'Someone reported, on the Tyrian side, that he had seen a vision in which Apollo told him that he would leave the city. Everyone suspected that the man had made up the story in order to curry favour with Alexander, and some of the younger citizens set out to stone him; he was, however, spirited away by the magistrates and took refuge in the temple of Heracles, where as a suppliant he escaped the people's wrath, but the Tyrians were so credulous that they tied the image of Apollo to its base with golden cords, preventing, as they thought, the god from leaving the city. (Transl. Welles 1963).

What all of these accounts have in common is that, unlike the stories of evocatio, they make no attempt to attribute the departure of the gods from soon to be conquered cities to the effect of a ritual or any other specific action performed by the besieging forces. As Poseidon's words indicate, gods choose to leave because they have no more reason to stay in a city that is no longer capable of providing them with proper worship. It appears that the Aeneis, which also makes no mention of the Greeks performing any rituals meant to compel the gods to abandon Troy, has closer ties to these accounts than to the ones of evocatio and may have been directly influenced by the Troades and other Greek tragedies covering the Trojan War. Servius' and Macrobius' attempts to link Vergil's verses to evocatio may be products of their desire to discover the origins of the mysterious ritual, characterized as arcanum et multis ignotum by Macrobius, in Rome's founding myths.

\section{References}

Austin R. G. (ed.) P. Vergili Maronis Aeneidos Liber Secundus. Oxford, Clarendon Press, 1973.

Church A. J., Brodribb W. J. The History of Tacitus. London, 1894.

Coleridge E. P. The Plays of Euripides, Vol I. London, Macmillan,1910.

Connington J.P. (ed.) Vergili Maronis Opera. London, Whittaker, 1863.

Fairclough H. R. (transl.), Goold, G. P. (rev.) Vergilius. Aeneid: Books 7-12. Appendix Vergiliana. Cambridge, MA, Harvard University Press, 1918.

Kaster, R. A. (ed., transl.) Macrobius. Saturnalia, Volume II: Books 3-5. Cambridge, MA, Harvard University Press, 2011.

Page T.E. (ed.) The Aeneid of Virgil. Books I-VI. New York, St. Martin’s Press, 1967.

Sedgwick A. P. (ed.) Vergili Maronis Aeneidos Liber II. Cambridge, University Press, 1884.

Welles C. B. (transl.) Diodorus Siculus. Library of History, Volume VIII: Books 16. 66-17. Cambridge, MA, Harvard University Press, 1963.

Whiston W. The Works of Flavius Josephus. London, Printing and Publishing Company, 1878.

For citation: Isaenko R.A. Verg. Aen. 2. 351-352: evocatio under Troy? Philologia Classica 2017, 12(2), 234-239. https://doi.org/10.21638/11701/spbu20.2017.212 
VERG. AEN. 2. 351-352: EVOCАТІО ПОД ТРОЕЙ?

Роман Андреевич Исаенко

Санкт-Петербургский государственный университет,

Российская Федерация, 199034, Санкт-Петербург, Университетская наб., 7-9;

isaenkora@mail.ru

Предметом статьи является двустишие, которое в «Энеиде» Вергилия произносит Эней, наблюдающий падение Трои и отмечающий, что город был покинут богами. Макробий и Сервий видят в этих строках указание на то, что перед штурмом Трои ахейцы исполнили обряд эвокации, заключавшийся в обращении полководца к божеству-покровителю осаждаемого города с просьбой принять сторону нападавших в обмен на почитание с их стороны. Статья ставит своей задачей критику этой интерпретации и предлагает возможную причину ее появления.

Ключевые слова: evocatio, Вергилий, Энеида, Сервий, Макробий.

Received: 01.08.2017

Final version received: 12.10.2017 